\title{
Volunteering among medical students during the COVID-19 pandemic: what should be taken into account?
}

\section{Voluntariado entre estudantes de medicina durante a pandemia de COVID-19: o que devemos considerar?}

\author{
Matheus Santarosa Cassiano' (1) | matheuscassiano76@gmail.com \\ Nelio Neves Veiga-Junior ${ }^{1}$ (1) neliojunior@hotmail.com \\ Luiz Gustavo Oliveira Brito' 10 Igobrito@unicamp.br \\ Silvia Maria Riceto Ronchim Passeri' (1) spasseri@unicamp.br \\ Angelica Maria Bicudo' 1 (1) angelicabicudo@gmail.com
}

\begin{abstract}
Introduction: during the COVID-19 pandemic, the universities suspended in-person activities and medical education adapted from the traditional format to virtual scenarios. Thus, the volunteering activities might improve the apprenticeship in critical situations and constitute a way to obtain competences and clinical skills.
\end{abstract}

Objective: to identify the frequency of student volunteering during the COVID-19 pandemic and the associated factors.

Methods: a cross-sectional study was performed targeting medical students in their last 3 years at a medical school in Brazil. Three hundred and fifty invitations were sent by email to ask students to participate in a self-administered, anonymous electronic survey during the pandemic. The primary outcome was the frequency of volunteer activities. Sociodemographic variables and characteristics of the medical students' activities were the dependent variables for the multivariate analysis that calculated the factors associated with volunteering.

Results: One hundred and twenty-five respondents (35.8\% response rate) were included in the analysis (no missing data). The frequency of volunteering was $52 \%$ and most of the participants were females $(63.2 \%)$ and all had access to online activities. Telemedicine was the most frequent activity (56/65). After the multivariate analysis, it was found that a family income of 5.1-10 minimal wages (OR=2.32[0.94-6.42]), expressing the ability and confidence in a pandemic situation ( $O R=4.91[1.49-16.2])$ and considering e-learning important before the pandemic (OR=16.46[1.35200.32]) and exposure of more than 120 minutes to social media platforms were less motivating for volunteering.

Conclusion: About half of the medical students volunteered during the COVID-19 pandemic. The presence of self-confidence, with previous training in a pandemic situation motivated the students to volunteer.

Keywords: Volunteering; COVID-19; Medical Student; Telemedicine; Medical Education.

\section{RESUMO}

Introdução: Durante a pandemia da Covid-19, as universidades suspenderam as atividades presenciais e o ensino médico adaptou-se do formato tradicional para os cenários virtuais. Assim, as atividades de voluntariado podem melhorar a aprendizagem em situações críticas e são uma forma de obter competências e habilidades clínicas.

Objetivo: Este estudo teve como objetivo identificar a frequência do voluntariado nos estudantes durante a pandemia da Covid-19 e seus fatores associados.

Método: Realizou-se um estudo transversal com estudantes de Medicina dos três anos finais de uma faculdade no Brasil. Trezentos e cinquenta alunos foram convidados via e-mail para uma pesquisa eletrônica anônima e autoaplicável, em meio à pandemia. O resultado primário foi a frequência das atividades voluntárias. Variáveis sociodemográficas e características da atividade dos estudantes foram as variáveis dependentes para análise multivariada dos fatores associados ao voluntariado.

Resultado: Incluíram-se 125 alunos (taxa de resposta de 35,8\%) na análise (sem dados ausentes). A frequência de voluntariado foi de 52\%, a maioria dos participantes era do sexo feminino (63,2\%), e todos tinham acesso a atividades on-line. A telemedicina foi a atividade mais frequente (56/65). Em análise multivariada, constatou-se que os seguintes fatores foram menos motivadores para o voluntariado: renda familiar entre 5, 1 e dez salários mínimos $(O R=2,32[0,94-6,42])$, capacidade e confiança em atuar numa situação de pandemia $(O R=4,91$ [1,49-16,2]), os alunos que consideraram importante uso do e-learning antes da pandemia $(O R=16,46[1,35-200,32])$ e exposição por mais de 120 minutos a plataformas de mídia social.

Conclusão: Cerca de metade dos estudantes de Medicina foram voluntários durante a pandemia da Covid-10. A presença de autoconfiança com aconsel hamento prévio em uma situação de pandemia motivou o aluno a se voluntariar.

Palavras-chave: Voluntariado; COVID-19; Estudantes de Medicina; Telemedicina; Educação Médica.

1 Universidade de Campinas, Campinas, São Paulo, Brazil.

Chief Editor: Rosiane Viana Zuza Diniz.

Associate Editor: Daniela Chiesa.

Received on 03/11/21; Accepted on 05/20/21.

Evaluated by double blind review process. 


\section{INTRODUCTION}

The outbreak of COVID-19 in January 2020 has rapidly transformed into a pandemic after the World Health Organization's classification. The public health emergency has motivated the implementation of social distancing measures and prohibition of non-essential services ${ }^{1}$, followed by universities that suspended in-person activities aiming at reducing students' mobility and, consequently. restricting disease transmission ${ }^{2}$. In medical schools, the migration to e-learning platforms was almost immediate and an alternative to adapt medical education from the traditional format to virtual scenarios ${ }^{3,4}$.

Although technology may represent an alternative to continuing knowledge ${ }^{5}$, the lack of solid evidence that it may be as effective as in-person teaching methodology for medical students brought concerns with regard to their personal and professional development ${ }^{6-8}$, and this challenge still needs clarification during the ongoing pandemic, as a second wave strikes Europe and North America. Therefore, medical students, more specifically those attending the last years of undergraduate medical school, suffer more anxiety, because they are at a crucial moment to obtain which cannot be obtained in a similar fashion through digital platforms.

However, the same clinical scenario is the most at-risk place for acquiring COVID-19 and several strategies should be proposed in the attempt to overcome prejudices due to the lack of clinical training in this group of students. The virtual discussion of real clinical-case scenarios and elective disciplines that improve the training in critical situations (telemedicine ${ }^{10}$ ), as well as volunteer activities, have been fundamental as a response to many health sectors ${ }^{11}$. Volunteering may be seen as an altruistic attitude, or an opportunity to learn from the situation, but in the presence of a pandemic, there might be other reasons ${ }^{12,13}$ and medical courses should be aware of them. Given that, we sought to identify the factors associated with choosing a volunteering activity among medical students attending the last years of medical school during the COVID-19 pandemic.

\section{METHODS}

\section{Study design and population}

A cross-sectional study was performed with students attending the fourth, fifth and sixth years (MS4, MS5 and MS6) at the School of Medical Sciences, University of Campinas (UNICAMP), Brazil. In Brazil, the undergraduate medical school takes six years, during which the MS4 students do rotations in clinical areas and begin to perform medical consultations (medical history plus physical examination) under supervision and the MS5-MS6 learn by practicing on their own but have the consultation revised by an attending physician ${ }^{14}$.
The study was approved by the Institutional Review Board of our institution (CAAE: 31785520.1.0000.5404, approved on May $29^{\text {th }}, 2020$ ) and the free and informed consent was obtained from all students before they were admitted into the study.

\section{Data collection}

A self-administered, anonymous, electronic survey was developed and administered using the web-based survey platform Google Forms (Alphabet Co., Mountain View, California). The survey instrument and instructions were provided in the Brazilian Portuguese language and links to the survey were distributed to the medical students via email individually; 350 invitations were sent on a weekly basis and the survey was conducted from May $31^{\text {st }}$ to July $14^{\text {th }}, 2020$.

\section{Volunteer activities}

Volunteer activities are defined as non-paid, freely offered activities performed by medical students, with no direct benefits to them and aimed at helping the population. They were considered outside the formal medical curriculum and divided into the following activities:

Telemedicine: after preparatory classes and under pedagogical guidance, medical students answer the population's questions presential or by telephone and provide counseling on hygiene measures, disease prevention and symptoms that require face-to-face care in health facilities.

Health Expeditionary: non-profit, non-governmental organization that provides medical care by screening suspected cases of COVID-19, where medical students seek to identify signs and symptoms of the disease; it is carried out through clinical presentations, making the decision to monitor a suspect case in the health facility or home.

Shifts: medical students could perform night calls with one resident from $6 \mathrm{pm}$ to midnight, at the Obstetrics and Gynecology discipline at the university Women's hospital, in a space next to the admission room, but with no contact with other scenarios, providing care to women with gynecological and obstetrical complaints, attendind a few number os cases. This option was considered later, because several MS reported they would like to continue to help the residents and physicians.

External Activities: another volunteer activity not related to the university's health service, such as the loan of electronic equipment (computers/laptops and tablets) and prepaid phones for internet access so that students could follow remote classes and keep up with their activities.

\section{Survey instrument}

The participants filled out a 21-item questionnaire specifically developed for our study, which was pilot-tested 
after a modified Delphi panel that consisted of physicians and tutors specialized in medical education and learning methods. It contains: sociodemographic, baseline information (age, gender, year of study, family income), multiple-choice, open-ended questions about internet access and education technology use (use of medias, time spent on social media and academic activities), questions about the students' capability to face an emergency related to a global health situation as volunteers and the developed activities; theoretical and practical learning methods, strengths and limitations of the medical school curriculum for undergraduate students. We also asked questions about teaching methods before and during the pandemic situation.

\section{Statistical analysis}

Continuous variables were expressed by mean and standard deviation or median/range, while categorical variables were described as percentages. The unpaired t-student test was performed for continuous variables and the chi-square test for binomial variables. The bivariate analysis was expressed as odds ratio with lower and upper limits within a 95\% confidence interval. The multivariate analysis was calculated by logistic regression including all independent variables, whose $p$-values were $<0.10$ in the final model. The significance level was set at $5 \%$. A statistical package was used for further analysis (Intercooled Stata 13.0, StataCorp, College Station, TX, US).

\section{RESULTS}

Of 350 invitations, 125 (35.8\%) responded and were included in the analysis. Response rates varied: $24.8 \%$ from the MS4, 37.6\% from MS5 and 37.6\% from the MS6. No incomplete responses were found. Table 1 shows the sociodemographic characteristics and the questionnaire responses by volunteers and non-volunteers. Among the participants, 79 were females (63.2\%) and $46(36.8 \%)$ males. All participants had access to the Internet and 102 (81.6\%) used a notebook, 10 (8\%) used a desktop computer and $13(10.4 \%)$ used smartphones and tablets. Sixtyfive $(52 \%)$ students were volunteers and the distribution of the activities were (more than one type of activity could be chosen): 56 worked with telemedicine, 16 worked with the Expeditionary Health team, 8 worked by taking medical night calls and 7 performed external activities. Among the volunteers, most of them were MS-5/6 (66.15\%); however, less than half of this medical class were volunteers - among the MS-4s, $70.97 \%$ were volunteers.

About the time spent on social media during a day, $24(19.2 \%)$ students accessed them for less than 120 minutes, 72 (57.6\%) spent between 120 and 360 minutes and 29 (23.2\%) more than 360 minutes. On the other hand, 80 (64.5\%) spent less than 120 minutes using the e-learning platforms.
Table 1. Variables according to the presence or absence of volunteer activities during COVID-19 pandemic among medical students (4-6 ${ }^{\text {th }}$-year medical students).

\begin{tabular}{cccc}
\hline \multirow{2}{*}{ Variables } & Volunteer & Control & p-value* \\
\cline { 2 - 3 } & $\mathbf{N}(\%)$ & $\mathbf{N}(\%)$ & \\
\hline Age (years) & & & 0.73 \\
$20-23$ & $29(44.6)$ & $24(40)$ & \\
$24-27$ & $28(43.1)$ & $30(50)$ & \\
$28+$ & $8(12.3)$ & $6(10)$ & \\
\hline Gender & & & 0.73 \\
Male & $23(35.4)$ & $23(38.3)$ & \\
Female & $42(64.6)$ & $37(61.7)$ & \\
\hline Internship Year & & & 0.01 \\
MS4 & $22(33.8)$ & $9(15.0)$ & \\
MS5-MS6 & $43(66.2)$ & $51(85.0)$ & \\
\hline
\end{tabular}

Family Income (multiple of 2020 minimal wage)

0.03

$\begin{array}{ccc}0-1 & 0(0) & 3(5.1) \\ 1.1-5.0 & 16(25.0) & 12(20.3) \\ 5.1-10 & 28(43.7) & 15(25.4) \\ >10 & 20(31.3) & 29(49.2)\end{array}$

\begin{tabular}{cccc}
$\begin{array}{c}\text { External Activity } \\
\text { Yes }\end{array}$ & $7(10.8)$ & $0(0)$ & 0.00 \\
No & $58(89.2)$ & $60(100)$ & \\
\hline $\begin{array}{c}\text { Telemedicine } \\
\text { Yes }\end{array}$ & $56(86.2)$ & $0(0)$ & 0.00 \\
No & $9(13.8)$ & $60(100)$ & \\
\hline $\begin{array}{c}\text { Expeditionary Health team } \\
\text { Yes }\end{array}$ & $16(24.6)$ & $0(0)$ & \\
No & $49(75.4)$ & $60(100)$ & \\
\hline
\end{tabular}

Night calls

0.00

$\begin{array}{ccc}\text { Yes } & 8(12.3) & 0(0) \\ \text { No } & 57(87.7) & 60(100)\end{array}$

Theoretical and practical preparation

0.02

Insufficient

$9(13.8)$

7 (11.7)

Somewhat insufficient

35 (55.4)

$47(78.3)$

Somewhat Sufficient

19 (29.2)

$6(10.0)$

Sufficient

1 (1.6)

$0(0)$

Exclusive e-learning for professional qualification

0.30

$\begin{array}{ccc}\text { Stayed the same } & 6(9.2) & 12(20.0) \\ \text { Somewhat worse } & 36(55.4) & 31(51.7) \\ \text { Much worse } & 14(21.5) & 7(11.7) \\ \text { Somewhat better } & 8(12.3) & 8(13.3) \\ \text { Much better } & 1(1.6) & 2(3.3)\end{array}$

Ability in a pandemic situation

0.10

$\begin{array}{lcc}\text { Not at all } & 33(50.8) & 39(65.0) \\ \text { Very Little } & 12(18.4) & 13(21.7) \\ \text { Somewhat } & 18(27.7) & 8(13.3) \\ \text { To a great extent } & 2(3.1) & 0(0)\end{array}$

Continue... 
Compared to MS5-MS6 students, MS-4s participation as volunteers was significantly lower $\left(X^{2}=5.94 ; p=0.01\right)$, as well as MS with higher family income $\left(X^{2}=8.96 ; p=0.03\right)$ and students that considered themselves more satisfied with previous theoretical and practical preparation $\left(x^{2}=9.28 ; p=0.02\right.$ ) (Table 1$)$.

When students were asked about their capability during theoretical and practical preparation for a public health emergency, 98 (78.4\%) considered themselves as not sufficient and $97(77.6 \%)$ did not feel capable to attending or dealing with an emergency in a global health situation, such as COVID-19.

Before the pandemic, $50.4 \%$ of the respondents considered important the teaching technologies (eg. e-learning). However, during the pandemic, the exclusive use of e-learning for theoretical activities and clinical case discussions were considered not sufficient for $70.4 \%$ of students about their professional qualification.

Univariate and multivariate analysis to the associated factors with volunteering were described in Table 2. After logistic regression, it was found that MS-5/6s were less associated with volunteering (OR, $0.21 ; 95 \% \mathrm{Cl}, 0.06-0.66)$, family income with 5.1-10 minimal wages more associated
Table 1. (Continuation) Variables according to the presence or absence of volunteer activities during COVID-19 pandemic among medical students (4-6 ${ }^{\text {th }}-y e a r$ medical students).

\begin{tabular}{cccc}
\hline \multirow{2}{*}{ Variables } & Volunteer & Control & \multirow{2}{*}{ p-value* } \\
\cline { 2 - 3 } & $\mathbf{N}(\%)$ & $\mathbf{N}(\%)$ & \\
\hline \multicolumn{2}{c}{ Time spent on social media platforms } & & 0.10 \\
$<120 \mathrm{~min}$ & $17(26.1)$ & $7(11.7)$ & \\
120-360 min & $33(50.8)$ & $39(65)$ & \\
$>360 \mathrm{~min}$ & $15(23.1)$ & $14(23.3)$ & \\
\hline E-learning before pandemic & & \\
Slightly Important & $1(1.6)$ & $5(8.3)$ & \\
Moderately Important & $27(41.5)$ & $29(48.3)$ & \\
Important & $32(49.2)$ & $21(35.0)$ & \\
Very important & $5(7.7)$ & $5(8.4)$ &
\end{tabular}

${ }^{*}$ Chi-square test for binomial variables and T-student for continuous variables.

Table 2. Univariate and multivariate analysis for variables associated to the presence of volunteer activities during COVID-19 pandemic.

\begin{tabular}{|c|c|c|c|c|}
\hline Variables & Crude Odds Ratio $(95 \% \mathrm{Cl})$ & p-value & Adjusted Odds Ratio $(95 \% \mathrm{Cl})$ & p-value \\
\hline \multicolumn{5}{|l|}{ Medical school year } \\
\hline 4th & $2.44(1.12-5.3)$ & .01 & ------------------ & \\
\hline 5 th/6th & $0.34(0.14-0.82)$ & .02 & $0.21(0.06-0.66)$ & .00 \\
\hline
\end{tabular}

Family Income (multiple of 2020 minimal wage)

$\begin{array}{lll}<1 & & \\ 1.1-5 & 1.93(0.75-4.95) & .17 \\ 5.1-10 & 2.7(1.16-6.31) & .02 \\ >10 & 0.69(0.39-1.21) & .20\end{array}$

Time spent on social media platforms (dummy variable)

\begin{tabular}{ccccc}
$<120 \mathrm{~min}$ & $1.1(0.71-1.71)$ & .65 & $1.17(0.06-20.1)$ & .91 \\
$120-360 \mathrm{~min}$ & $0.45(0.14-1.44)$ & .18 & $0.1(0.02-0.42)$ & .00 \\
$>360 \mathrm{~min}$ & $1.28(0.54-3.02)$ & .57 & $0.16(0.03-0.76)$ & .02 \\
\hline
\end{tabular}

Ability in a pandemic situation

Not at all

Extraordinarily little

Somewhat

$0.84(0.53-1.34)$

$1.09(0.43-2.71)$

$2.65(1.02-6.89)$

To a great extent

E-learning before pandemic

Slightly Important

Moderately Important Important

Especially important

$\begin{array}{cc}0.20(0.02-1.71) & .14 \\ 4.65(0.51-42.43) & .17 \\ 7.61(0.83-69.9) & .07 \\ 4.99(0.41-59.65) & .20\end{array}$

$2.45(0.74-8.07)$

.14

$2.32(0.94-6.42)$ .10 . 
with volunteering (OR, 2.32; 95\% Cl, 0.94-6.42). Exposure to social media platforms between 120-360 minutes in social media platforms (OR, $0.1 ; 95 \% \mathrm{Cl}, 0.02-0.42)$ and over 360 minutes $(\mathrm{OR}=0.16[0.03-0.76])$ reduced the risk for volunteering. Interestingly, MS that considered themselves able to face a pandemic situation (OR 4.91; 95\%Cl, 1.49-16.2) and that presented e-learning modules before pandemic $(\mathrm{OR}=16.46[1.35-200.32])$ were risk factors for being volunteers (Table 2).

\section{DISCUSSION}

This study has identified factors associated with volunteer activities among medical students attending the last years of undergraduate school during the COVID-19 pandemic. Students attending the $4^{\text {th }}$ year of the medical course, students with family income between 5-10 minimum wages, and students who felt more confident and capable to face the pandemic were more prone to be volunteers. Students that more often used social media networks showed a low probability of being volunteers.

An interruption of the educational process of the medical curriculum was expected to happen during the COVID-19 pandemic ${ }^{11}$, as we were not prepared to deal with a situation like that from a public health standpoint and the resources provided to students by the institutions were tested during this unprecedented period. During this survey, an attempt was made to identify medical students willing to be volunteers during a healthcare emergency situation, and we found that few students felt prepared regarding their abilities and previous experiences ${ }^{13}$, and many thought that the lack of full medical training would compromise their assistance to patients, even under supervision ${ }^{14,15}$. It was possible to observe during this pandemic, the unraveling of the scenarios in a virtual environment and how damage to the medical education could be minimized-that is, the fact that the e-learning structure was not completely prepared for what was coming ${ }^{16}$.

However, facing COVID-19 can have a positive impact promoted by medical students ${ }^{17}$. In Switzerland, students supervised by medical tutors in a critical-care scenario have demonstrated that the medical students felt motivated to work and learn, and the experience was considered feasible and safe ${ }^{18}$. In Brazil and United States ${ }^{19}$, medical students were submitted to a compulsory interruption of their clinical rotations and did not have a central role when facing this crisis, if one remembers that these countries had the largest death tolls worldwide ${ }^{20}$. This can be a controversial discussion, and there are pros and cons to both opinions on exposing a medical student to a pandemic situation.

The MS-4 have their first exposure to patient care ${ }^{14}$, and faced the interruption of outpatient and inpatient clinical rotations $s^{22,23}$. Volunteering can be a positive stimulus as the student can consider the unpredictability of the scenario, without knowing when they are coming back to the "normal" routine. This experience can motivate them to have contact with clinical experiences ${ }^{24}$; however, they showed less interest in volunteering than MS-5 and MS-6, and it is possible that the latter group considered the longer duration of the pandemic and having to undergo a transition to become physicians with less practical training. In addition, the unpredictability of the end of the medical course due to the pandemic ${ }^{21}$, as previous studies have shown that medical students may feel psychologically stress before the residency selection process ${ }^{25}$. Many countries, such as United Kingdom and United States, are changing the residency process to a virtual format and the new scenario can add stress to the process ${ }^{26}$.

During the COVID-19 pandemic, the use of social media has disseminated a great amount of information, and this certainly contributed to misinformation and fake news ${ }^{27}$. This trend may have impacted on the interest to be a volunteer; we have found that spending longer periods on social media decreased the interest to be a volunteer, and this can be explained by the fact that wrong information can generate high levels of stress and fear/uncertainty ${ }^{27,28}$. Social media exposure (SME) may cause misinformation and this can affect the mental health of users ${ }^{29}$ and compromise their willingness to participate in other activities during a crisis. Humanitarian crises may have consequences on the mental health of survivors ${ }^{28}$ and usually, the most affected population live in low- and middle-income countries (LMICs) $)^{30,31}$, such as Brazil.

Many health determinants, such as family income, may impact on the risk and outcomes caused by SARS-CoV-2 ${ }^{32}$. For individuals with a low socioeconomic level, social distancing may be more difficult, due to overcrowded housing and difficulty to maintain jobs with the home-office modality during the pandemic ${ }^{33}$. Such evidence may be related to difficulties that low-income students had to struggle with; many could not face the challenge of staying in the city where they were attending their medical school as the economic crisis was affecting many families; it is known that economic consequences secondary to restrictive measures have caused a global increase in unemployment rates ${ }^{34}$.

Students that felt prepared to face a global health emergency were more prone to be volunteers, and literature has shown that attitudes and previous knowledge may influence the student's decision to volunteer ${ }^{35}$. A Canadian study analyzed factors and attitudes of medical students who chose to volunteer during the influenza pandemic and reported that a previous volunteering experience was a strong predictor of being available to collaborate in that circumstance ${ }^{36}$. Other variables, such as age 
and gender ${ }^{36}$ may also be related to volunteering; however, our study did not identify these associations.

Our study has some limitations, which include the nonresponse bias inherent to its survey design and the sample that may be biased by self-selection, as the sample size was not calculated. If responders were more interested in being a volunteer than those that did not respond, then our results would be overly optimistic about the factors associated to participation in volunteer activities. Secondly, the impact of a higher risk of severe illness caused by Covid-19 infection was not directly measured among the responders. Another one is that all the students who answered the survey came from a single university located in the same country, which does not allow us to generalize our results.

The strengths of our study include the fact that it was conducted in a country that represents the third place regarding the number of cases and the second in death rates caused by COVID-19 and that has faced the collapse of the public health system in many cities around its national territory. Our response rate was satisfactory and compatible with other surveys.

COVID-19 pandemic has led our society to reshape itself and medical schools have undergone modifications aiming to face this pandemic. Medical students were questioned about their role during this pandemic period. It was concluded that half of our sample participated in volunteer activities during the COVID-19 pandemic and a previous, confident attitude towards a public health emergency increased the odds of working as a volunteer.

\section{CONCLUSION}

COVID-19 pandemic has led our society to reshape itself and medical schools have undergone modifications aiming to face this pandemic. Medical students were questioned about their role during this pandemic period. It was concluded that half of our sample participated in volunteer activities during the COVID-19 pandemic and a previous, confident attitude towards a public health emergency increased the odds of working as a volunteer. It is possible that the volunteer activities performed by medical students, with a high-quality training, during this pandemic might change the public health system care, especially in low-and-middle income countries, facilitating access to the service and care of patients with lower clinical complexity.

\section{ACKNOWLEDGMENTS}

We would like to express our gratitude to Dr. Maya Hammoud, Professor of Medicine from the University of Michigan, for her great suggestions to improve our manuscript.

\section{AUTHORS' CONTRIBUTION}

All authors contributed to the study research, design and writing of this manuscript.

\section{CONFLICTS OF INTEREST}

The authors declare no conflicts of interest.

\section{SOURCES OF FUNDING}

The authors declare no sources of funding.

\section{REFERENCES}

1. World Health Organization. [access in 25 oct 2020]. Available from: https:// covid19.who.int/.

2. Minister Department of Health. [access in 25 oct 2020]. Available from https://www.saude.gov.br/images/pdf/2020/April/09/be-covid-08final-2.pdf.

3. Akers A, Blough C, lyer MS. COVID-19 Implications on Clinical Clerkships and the Residency Application Process for Medical Students. Cureus. 2020;12(4):e7800

4. Tempski $P$, Danila AH, Arantes-Costa FM, Siqueira MAM, Torsani MB Martins MA. The COVID-19 pandemic: time for medical teachers and students to overcome grief. Clinics. 2020:75

5. Wittich CM, Agrawal A, Cook DA, Halvorsen AJ, Mandrekar JN, Chaudhry $\mathrm{S}$, et al. E-learning in graduate medical education: Survey of residency program directors. BMC Med Educ. 2017;17(1).

6. Regmi K, Jones L. A systematic review of the factors - Enablers and barriers - Affecting e-learning in health sciences education. BMC Med Educ. 2020;20(1).

7. Cornine A. Reducing Nursing Student Anxiety in the Clinical Setting: An Integrative Review. Nurs Educ Perspect. 2020;41(4):229-34.

8. Wang C, Horby PW, Hayden FG, Gao GF. A novel coronavirus outbreak of global health concern. Lancet 2020;395(10223):470-3.

9. Eftekhar H, Labaf A, Anvari P, Jamali A, Sheybaee-Moghaddam F. Association of the pre-internship objective structured clinical examination in final year medical students with comprehensive written examinations. Med Educ Online. 2012;17(1). doi: 10.3402/meo.v17i0.15958.

10. Rose S. Medical Student Education in the Time of COVID-19. JAMA - J Am Med Assoc. 2020;323(21):2131-2.

11. O'Byrne L, Gavin B, McNicholas F. Medical students and COVID-19: the need for pandemic preparedness. J Med Ethics. 2020;46(9):623-62.

12. Miller DG, Pierson L, Doernberg S. The Role of Medical Students During the COVID-19 Pandemic. Ann Intern Med. 2020;173(2):145-6.

13. Gouda P, Kirk A, Sweeney AM, O'Donovan D. Attitudes of Medical Students Toward Volunteering in Emergency Situations. Disaster Med Public Health Prep. 2019;14(3):308-11.

14. Schweller M, Costa FO, Antônio MÂRGM, Amaral EM, De Carvalho-Filho MA. The impact of simulated medical consultations on the empathy levels of students at one medical school. Acad Med. 2014;89(4):632-7.

15. Mortelmans LJM, Bouman SJM, Gaakeer MI, Dieltiens G, Anseeuw K, Sabbe MB. Dutch senior medical students and disaster medicine: a national survey. Int J Emerg Med. 2015;8(1).

16. Mortelmans LJM, Dieltiens G, Anseeuw K, Sabbe MB. Belgian senior medical students and disaster medicine, a real disaster? Eur J Emerg Med 2014;21(1):77-8.

17. Newman NA, Lattouf OM. Response to COVID-19 pandemic: Beyond medical education in Brazil. J Card Surg. 2020;35(6):1176.

18. Klasen JM, Meienberg A, Nickel C, Bingisser R. SWAB team instead of SWAT team: medical students as front-line force during the COVID-19 pandemic. Med Educ. 2020;13:14224. 
19. Association of American Medical Colleges. Important guidance for medical students on clinical rotations during the coronavirus (COVID-19). [access in 25 oct 2020]. Available from: https://www.aamc.org/newsinsights/press-releases/important-guidance-medical-students-clinicalrotations-during-coronavirus-covid-19-outbreak.

20. Ferrel MN, Ryan JJ. The Impact of COVID-19 on Medical Education. Cureus. 2020;12(3):e7492.

21. Baker DM, Bhatia S, Brown S, Cambridge W, Kamarajah SK, McLean KA, et al. Medical student involvement in the COVID-19 response. Lancet. 2020;395(10232):1254.

22. lacobucci G. Covid-19: medical schools are urged to fast-track final year students. BMJ. 2020;368:m1064.

23. Taghrir MH, Borazjani R, Shiraly R. COVID-19 and iranian medical students; A survey on their related-knowledge, preventive behaviors and risk perception. Arch Iran Med. 2020;23(4):249-54.

24. Tang W, Hu T, Hu B, Jin C, Wang G, Xie C, et al. Prevalence and correlates of PTSD and depressive symptoms one month after the outbreak of the COVID-19 epidemic in a sample of home-quarantined Chinese university students. J Affect Disord. 2020;274:1-7.

25. Gibbs T. The Covid-19 pandemic: Provoking thought and encouraging change. Med Teach. 2020;42(7):738-40.

26. Torales J, O'Higgins M, Castaldelli-Maia JM, Ventriglio A. The outbreak of COVID-19 coronavirus and its impact on global mental health. Int J Soc Psychiatry. 2020;66(4):317-20.

27. Purgato M, Gastaldon C, Papola D, van Ommeren M, Barbui C, Tol WA. Psychological therapies for the treatment of mental disorders in lowand middle-income countries affected by humanitarian crises. Cochrane Database Syst Rev. 2018;7(7):CD011849.
28. Gao J, Zheng P, Jia Y, Chen H, Mao Y, Chen S, et al. Mental health problems and social media exposure during COVID-19 outbreak. PLoS One. 2020;15(4):e0231924.

29. Leaning J, Guha-Sapir D. Natural Disasters, Armed Conflict, and Public Health. N Engl J Med. 2013;369(19):1836-42.

30. Themnér L, Wallensteen P. Armed conflicts, 1946-2014. Journal of Peace Research. 2015;52(4):536-50.

31. Abrams EM, Szefler SJ. COVID-19 and the impact of social determinants of health. Lancet Respir Med. 2020;8(7):659-61.

32. Patel JA, Nielsen FBH, Badiani AA, Assi S, Unadkat VA, Patel B, et al. Poverty, inequality and COVID-19: the forgotten vulnerable. Public Health. 2020;183:110-1.

33. Kawohl W, Nordt C. COVID-19, unemployment, and suicide. The lancet Psychiatry. 2020;7(5):389-90.

34. Stukas AA, Snyder M, Clary EG. The effects of "mandatory volunteerism" on intentions to volunteer. Psychol Sci. 1999;10(1):59-64.

35. Rosychuk RJ, Bailey T, Haines C, Lake R, Herman B, Yonge $O$, et al. Willingness to volunteer during an influenza pandemic: Perspectives from students and staff at a large Canadian University. Influenza Other Respi Viruses. 2008;2(2):71-9.

36. Zweigenhaft RL, Armstrong J, Quintis F, Riddick A. The motivations and effectiveness of hospital volunteers. J Soc Psychol. 1996;136(1):25-34. 